\title{
EXPERIMENTAL STUDY OF DEPTH VARIATION IN FLANGED RIBBED LIGHTWEIGHT CONCRETE SLABS
}

\section{*Samer S. Abdulhussein ${ }^{1}$}

1) College of Engineering, Mustansiriyah Univ., Baghdad, Iraq

2) College of Engineering, Mustansiriyah Univ., Baghdad, Iraq

\begin{abstract}
Ribbed slabs provide a lighter and stiffer slab than an equivalent traditional slab with minimizing the total volume of the materials. Four flanged one-way lightweight concrete ribbed slabs have been cast then tested under two-point load as simply supported up to failure. The main investigated variable was the ratio of the rib depth to the overall beam depth. All the slabs have the same concrete volume and the same steel reinforcement area. Also, the width of the rib is equal to the slab thickness as a constraint condition in all the slabs. Data were recorded at the loading stages to determine the load capacity and the deflection. The results showed that increasing the ratio of the rib depth to the overall beam depth improved the structural behavior by increasing the carrying load capacity and reduces the deflection up to a certain limit. It was found that the ideal ratio was approached (0.835).
\end{abstract}

Keywords: lightweight concrete, ribbed slab, beam depth, rib depth.

\section{Introduction}

The slab is a very significant sustainable structural element in buildings and one of the largest consumption members of concrete [1]. Several studies have been conducted to minimize the self-weight of the slabs, with the maintenance of flexural strength as it was decreasing the weight of the slab would result in decreasing the deflection and making larger lengths of the span possible to achieve [2]. The one-way slab is one of the simplest forms of solid slab. The ribbed slab system consists of a

\author{
Asst. Prof. Dr. Ashraf A. Alfeehan ${ }^{2}$
}

series of small closed spaced concrete tee beams. To reduce the self-weight of the slab, the ineffective concrete area between the joists in the tension zone is left open or filled with lightweight materials [3]. Using LightWeight Concrete (LWC) is often based upon reducing the cost of the project, enhanced functionality, or combining both. The estimation of the total project cost is highly important in the case of consideration of the LWC, due to the fact that the cost per cubic yard (or cubic meter) is often greater compared to a comparable ordinary concrete unit [4-6]. The main utilization of the structural light-weight concrete is reducing concrete structure's dead load, which in turn provides the designer with the ability to reduce the size of footings, columns, as well as other bearing structural elements. The marginally higher LWC cost has been offset with elements' size reduction, reduced concrete volume, and less reinforcing steel, which results in lower overall costs. Structural LWC provides a more efficient strength to weight ratio in structural elements. A. Abdulkareem and A. Alfeehan, (2018) [7] tested four non-flanged one-way LWC ribbed slabs, which includes three ribbed and one flat slab. Non-linear finite element analysis has been conducted, with the use of the 
ANSYS15 software. Reinforcing steel has been a bi-directional multi-layered of a microreinforcement of a $(1.55 \mathrm{~mm})$ diameter and a $(10 \mathrm{~mm})$ clear spacing in every direction. The basic researched factor is a rib depth to the overall beam depth $\left(h_{w} / h\right)$ ratio. All of the slabs are of identical concrete volumes and an identical ratio of the steel reinforcement. The increasing ratio of $\left(h_{w} / h\right)$ has resulted in improving structural behavior with the increase of load-carrying capacity and reducing the limit of the deflection. Huang et al., (2019) [8] studied the flexural behavior of four LWC multi-ribbed composite slab with filled lightweight blocks with one ordinary concrete slab under static tests. The research showed that the bending failure process of LWC multi-ribbed composite slab specimens is the same as the process of the ordinary concrete slab. The ultimate bearing capacity of LWC multi-ribbed composite slab specimens increases by $(47.50 \%$ to $37.60 \%$ ) compared with an ordinary one, while their weight is decreased by $(17 \%$ to $31.6 \%$ ), respectively. De Oliveira et al., (2014) [9] have conducted a study on 8 panels of the ribbed slab for finding out the slab portion sharing in the resistance of shear stresses. The total panel depth was $300 \mathrm{~mm}$ with a variety of flange thickness values. Results have shown that the important flange contribution is in the resistance of shear stresses. The flexural steel strain has been proportionate to flange depth increase, giving a higher level of ductility. Increasing panel width didn't result in a considerable ultimate load increase.

\section{Scope of the Study}

The present work adopted the LWC mix design that had been used by A. Abdulkareem and A.
Alfeehan [7]. The mix design gave a (2.19) of a strength-to-density ratio where the strength in (MPa) and the density in $\left(\mathrm{kg} / \mathrm{m}^{3}\right)$. Researchers in this study attempt to find an ideal crosssection through researching the impact of $\left(\mathrm{h}_{\mathrm{w}} / \mathrm{h}\right)$ ratio in flanged light-weight ribbed slabs. There have been two conditions taken under consideration in the present work. The first one is that the width of the rib equal to a thickness of the slab and the second one is that the areas of steel reinforcement and concrete crosssection are identical in all of the flanged ribbed slabs that have been tested.

\section{Experimental Investigation}

The experimental program includes the cast and tests four specimens of one-way flanged LWC ribbed slabs with constant double $\mathrm{T}$ crosssectional area of $(34200) \mathrm{mm}^{2}$, (1100) $\mathrm{mm}$ in length, and (450) $\mathrm{mm}$ in width with different dimensions of flange thickness, web width and spacing between the ribs. The width of the web (rib) was kept always equal to the thickness of the flange. The variable investigated in this study was the $\left(h_{w} / h\right)$ ratio. The steel reinforcement ratio was also constant in all specimens. The details and geometry of the ribbed slab section have been illustrated in Fig. 1. The slab details have been presented in Table1. The specimens of the ribbed slab were designed based on the ACI-318, (2014) [10].

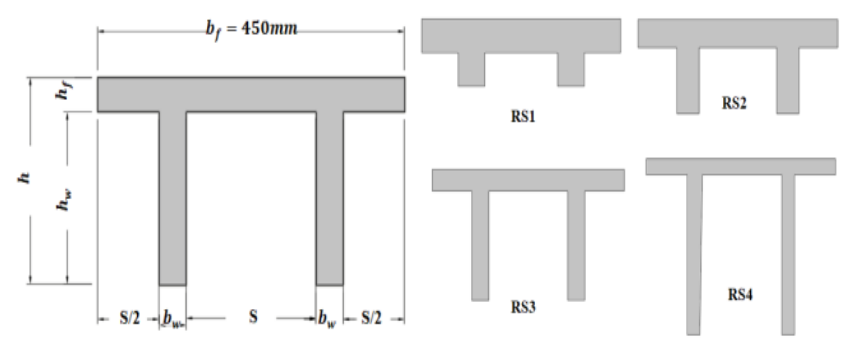

Figure 1. Geometry of ribbed slab sections 
Table 1. Details and designation of the experimental slabs

\begin{tabular}{ccccccc}
\hline Slab Coding & $\mathrm{h}_{f}(\mathrm{~mm})$ & $\mathrm{b}_{\mathrm{w}}(\mathrm{mm})$ & $\mathrm{h}_{\mathrm{w}}(\mathrm{mm})$ & $\mathrm{S}(\mathrm{mm})$ & $\mathrm{h}(\mathrm{mm})$ & $\mathrm{h}_{\mathrm{w}} / \mathrm{h}$ \\
$\mathrm{RS} 1$ & 60 & 60 & 60 & 165 & 120 & 0.5 \\
$\mathrm{RS} 2$ & 50 & 50 & 117 & 175 & 167 & 0.701 \\
$\mathrm{RS} 3$ & 40 & 40 & 202 & 185 & 242 & 0.835 \\
$\mathrm{RS} 4$ & 30 & 30 & 345 & 195 & 375 & 0.92 \\
\hline
\end{tabular}

RS: Ribbed Slab, (1, 2, 3 and 4): The number in the slab coding refers to the $\left(h_{w} / h\right)$ ratio, $h_{f}$ : the thickness of the flange, $b_{w}$ : width of the web, $h_{w}$ : height of rib, $S$ : clear space between ribs, h: overall depth of the slab, $h_{w} / h$ : depth of rib to an overall depth of the slab.

The used materials and concrete mix proportions for required compressive strength equal to $(34 \mathrm{MPa})$ are presented in Table 2. Each web of the LWC ribbed slab was reinforced with one deformed steel bar of (Ø6) $\mathrm{mm}$ as longitudinal bottom tension reinforcement. The slab was designed to fail by tension mode under the applied loads. Mesh reinforcement of (Ø4) mm diameter bars at $(50) \mathrm{mm} \mathrm{c} / \mathrm{c}$ spacing in each direction was used in the slab flange to achieve the requirements of the temperature and shrinkage reinforcement. To prevent the shear failure occurring, (7-Ø4) $\mathrm{mm}$ diameter stirrups were provided in each web. Four molds used for casting the specimens were made from plywood illustrated in Fig. 2. The details of the reinforcement are illustrated in Fig. 3. Table 3 summarizes the properties of the reinforcing bars.

Table2. LWC mix

$\begin{array}{cc}\text { Material } & \begin{array}{c}\text { Quantity } \\ \mathrm{kg} / \mathrm{m}^{3}\end{array} \\ \text { Cement (OPC Type I) } & 800 \\ \text { Sand (pass from sieve } 600 \mu \mathrm{m}) & 800 \\ \text { Silica Fume (8\% of wt. of cement) } & 64 \\ \text { Limestone 95\% pass-through the sieve } 90 & 320 \\ \mu \mathrm{mm}(40 \% \text { of wt. of cement) } & \\ \text { w/c (33\% of wt. of the cement) } & 264 \\ \text { Super-plasticizer liter } / \mathrm{m}^{3}(6 \% \text { of the } \\ \text { cementitious materials) } \\ \text { Aluminum powder }(0.20 \% \text { of wt. of the } \\ \text { cement) }\end{array}$

Table 3. Properties of the reinforcing bars

\begin{tabular}{cccc}
\hline Diameter & Yield & Ultimate & Elongatio \\
$(\mathrm{mm})$ & Stress(MPa & Stress (MPa) & $\Delta \mathrm{L} \%$ \\
5 (high strength' & 1640 & 1900 & 11.5 \\
6 (Deform) & 449 & 640 & 8.6 \\
\hline
\end{tabular}

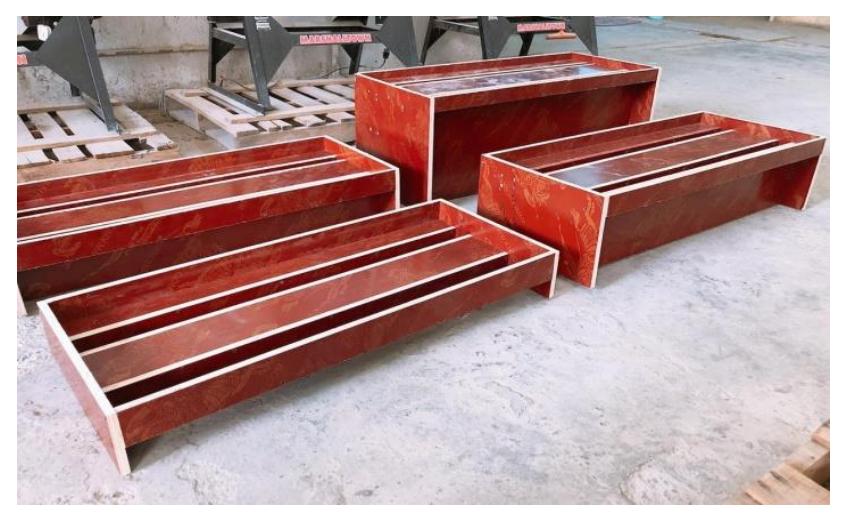

Figure 2. Plywood molds of ribbed slabs

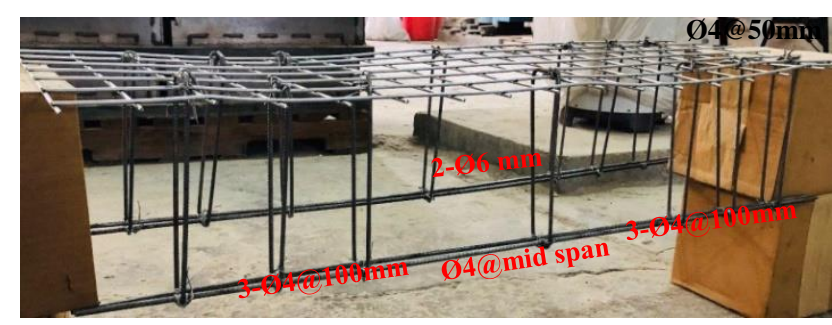

Figure 3. Details of steel bars reinforcement

All slabs are tested up to failure by using a system of a hydraulic universal testing machine. The test of specimens is a simply supported test by a two-point load. The clear span of the tested slab was (1000) $\mathrm{mm}$ and the clear distance between the point loads was $(340 \mathrm{~mm})$ that has been maintained constant for all slabs, as can be seen in Fig. 4. Fig. 5 shows the ribbed slab specimen under testing. The test carried out at 
the structural lab in the College of Engineering, Mustansiriyah University.

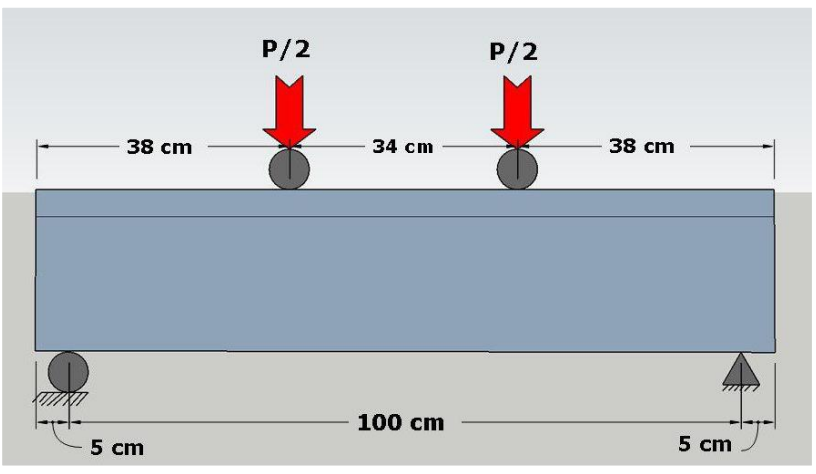

Figure 4. Details of the slab test.

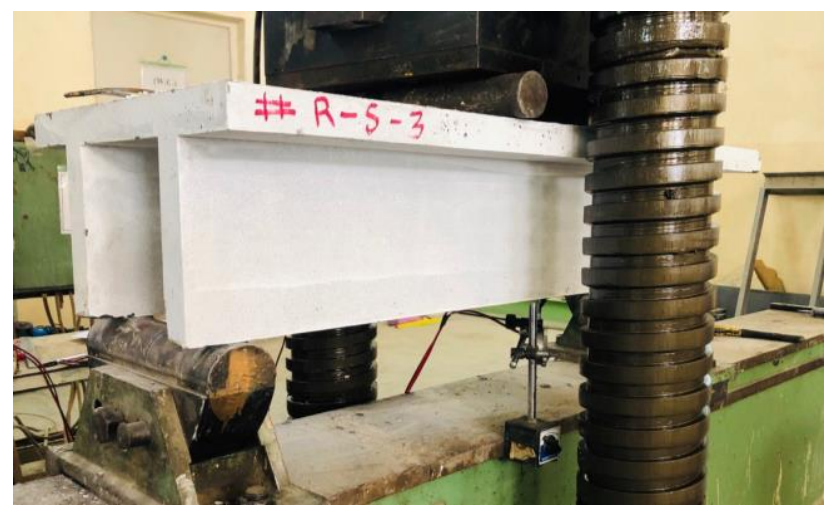

Figure 5. Testing of slab specimen.

\section{Results and Discussions}

Throughout the tests, all necessary measurements and notices, for each panel specimen were observed. The first crack and ultimate loads are logged. The test results have been recorded, summarized, and provided in Table 4. At early loading stages, the first cracks emerge in mid-span at the bottom face of the zone of the tension of each web at earlier loads. As the load increases, the cracks become wider progressively. A few cracks in each web extend to the bottom face of the flange and connected to the other web from the other side until the failure, while most of the cracks stopped on the web. Figure 6 shows the failure modes of the ribbed slabs tested in this work.

According to the results that have been plotted in Fig. 7 and Fig. 8, the increase of $\left(h_{w} / h\right)$ ratio improved the load-carrying capacity and decreased deflection. The increasing $\left(\mathrm{h}_{\mathrm{w}} / \mathrm{h}\right)$ ratio, with rib width to slab flange thickness equality condition, played an important role in increasing flexural stiffness up to a certain limit. The results showed that the suitable ratio of $\left(h_{w} / h\right)$ was $(0.835)$. The results can attribute that the distribution of moments along the parallel ribs is dependent upon the aspect ratio of the section of the rib and the relative stiffness of the slab and the ribs. The cracking and ultimate loads before and after this ratio in specimens (RS2 and RS4) appeared less valuable than the loads in (RS3). It demonstrates that this percentage close to the optimum ratio.

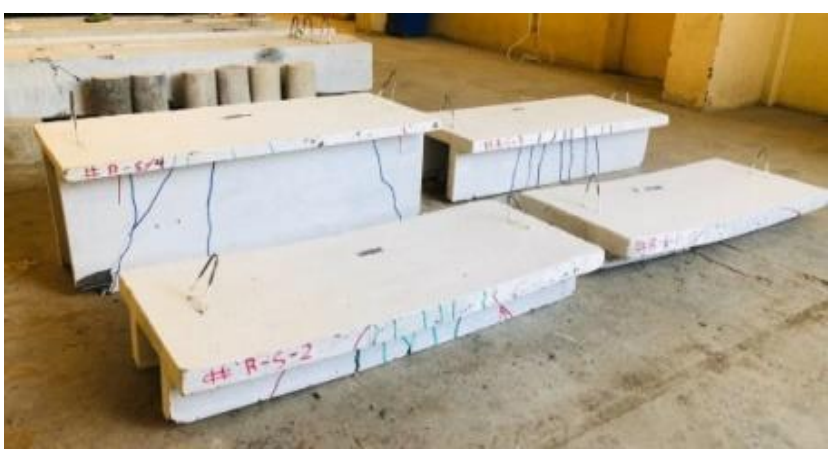

Figure 6. Failure mode of the tested ribbed slabs

Table 4. Loads and deflections for the first cracking and ultimate loading stages

\begin{tabular}{ccccccc}
\hline $\begin{array}{c}\text { Slab } \\
\text { Coding }\end{array}$ & $\begin{array}{c}\text { First } \\
\text { Cracking } \\
\text { Load }\left(\mathrm{P}_{\mathrm{cr}}\right) \mathrm{kN}\end{array}$ & $\begin{array}{c}\text { Deflection at } \\
\text { Cracking Load } \\
\left(\Delta_{\mathrm{cr}}\right) \mathrm{mm}\end{array}$ & $\begin{array}{c}\text { Ultimate } \\
\text { Load }\left(\mathrm{P}_{\mathrm{u}}\right) \\
\mathrm{kN}\end{array}$ & $\begin{array}{c}\% \text { of Difference } \\
\text { in Ultimate } \\
\text { Load }\end{array}$ & $\begin{array}{c}\text { Ultimate } \\
\text { Deflection }\left(\Delta_{\mathrm{u}}\right) \\
\mathrm{mm}\end{array}$ & $\begin{array}{c}\% \text { of Difference } \\
\text { in Ultimate } \\
\text { Deflection }\end{array}$ \\
RS1 & 15 & 0.67 & 60 & 0 & 13.64 & 0 \\
RS2 & 17.5 & 0.6 & 72.5 & +20.83 & 11.87 & -12.79 \\
RS3 & 20 & 0.47 & 92.5 & +27.59 & 9.18 & -22.66 \\
RS4 & 15 & 0.51 & 55 & -40.54 & 9.78 & -6.53 \\
\hline
\end{tabular}




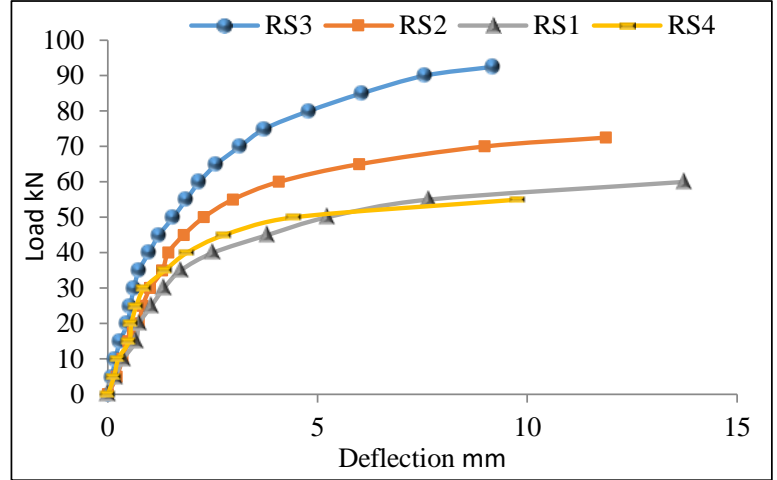

Figure 7. Effect of $\left(h_{w} / h\right)$ ratio on the load-deflection relationship.

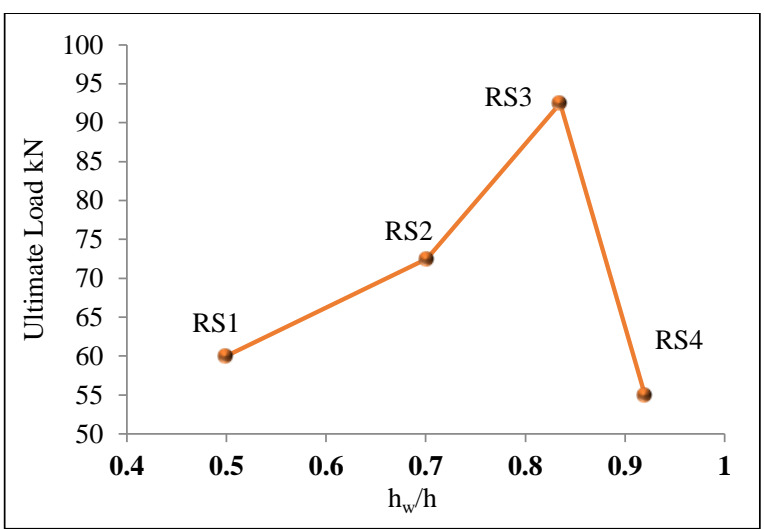

Figure 8. Effect of $\left(h_{w} / h\right)$ ratio in the ribbed slabs on the ultimate load.

\section{Conclusions}

Through the laboratory tests carried out in this study and based on the results obtained, the next conclusions might be reached:

1. The increasing ratio of $\left(\mathrm{h}_{\mathrm{w}} / \mathrm{h}\right)$ with an identical concrete volume and reinforcement ratio results in improving structural behavior by increasing the flexural stiffness and the load-carrying capacity as well as reducing the deflection up to a specific level.

2. The increase of $\left(h_{w} / h\right)$ ratio, with rib width and slab thickness equality condition, significantly impacts increasing flexural stiffness and enhancing the panel's structural performance.

3. The optimum $\left(\mathrm{h}_{\mathrm{w}} / \mathrm{h}\right)$ ratio has been slightly approaching (0.835) in the ribbed slabs and the ultimate load capacity increased by
$(54.17 \%)$ in comparison with $\left(\mathrm{h}_{\mathrm{w}} / \mathrm{h}\right)$ ratio $(0.5)$.

\section{Conflict of interest}

The authors certify that they have no affiliations with or involvement in any organization or entity with any financial interest or nonfinancial interest in the subject matter or materials discussed in this manuscript.

\section{Acknowledgments}

The authors would like to thank the College of Engineering at Mustansiryah University (www.uomustansiriyah.edu.iq), Baghdad-Iraq, for their support in this study.

\section{References}

1. Chung, J.H., Choi H.K., Lee S.C., and Choi C.S., (2011), "Flexural Capacities of Two-Way Hollow Slab with Donut Type Void," Proceeding of annual conference of the architectural institute of Korea., 9-20.

2. Marais, C, (2009)., "Design Adjustment Factors and the Economical Applications of Concrete Flat-Slabs with Internal Spherical Voids in South Africa", M.Sc. Thesis, University of Pretoria, August.

3. Donahey, R. C., and Darwin, D. (1988), "Web openings in composite beams with ribbed slabs', Journal structural Engineering.114, 3, 518-534.

4. Guide for Structural Lightweight Aggregate Concrete, (2003), ACI 213 R, American Concrete Institute, Farmington Hills, MI, USA.

5. R. Shabbar, N. Noordin, E. Dawood, and M. Z. Sulieman, (2010), "Comparison between ribbed slab structure using lightweight foam concrete and solid slab structure using normal concrete," Concr. Res. Lett., vol. 1, no. 1, pp. 19-34.

6. D. Wang and J. Li, (2020), "Experimental 
Analysis and Research on New Concrete Multi-ribbed Beam Hollow Floor," E\&ES, vol. 446, no. 2, p. 22040.

7. A. Abdulkareem, T. and A. Alfeehan, A. (2018) "Effect of the Rib Depth to the Overall Beam Depth Ratio in the Lightweight One-Way Ribbed Slabs," International Journal of Engineering \& Technology, 7(4.20), p. 438. doi: 10.14419/ijet.v7i4.20.26239.

8. Huang, W. et al. (2019) "Experimental Study on Flexural Behaviour of Lightweight Multi-Ribbed Composite Slabs," Advances in Civil Engineering, 2019. doi: 10.1155/2019/1093074.

9. de Oliveira, W. M. Souza., and T. R. G. Caetano., (2014), "Shear strength of reinforced concrete one-way ribbed slabs."RIEM-Revista IBRACON de Estruturas e Materiais, Vol.4, Issue.5.

10. ACI-318 (2014) Building Code Requirements for Structural Concrete (ACI 318S-14) and Commentary (ACI 318SR14), ACI 318-14. 